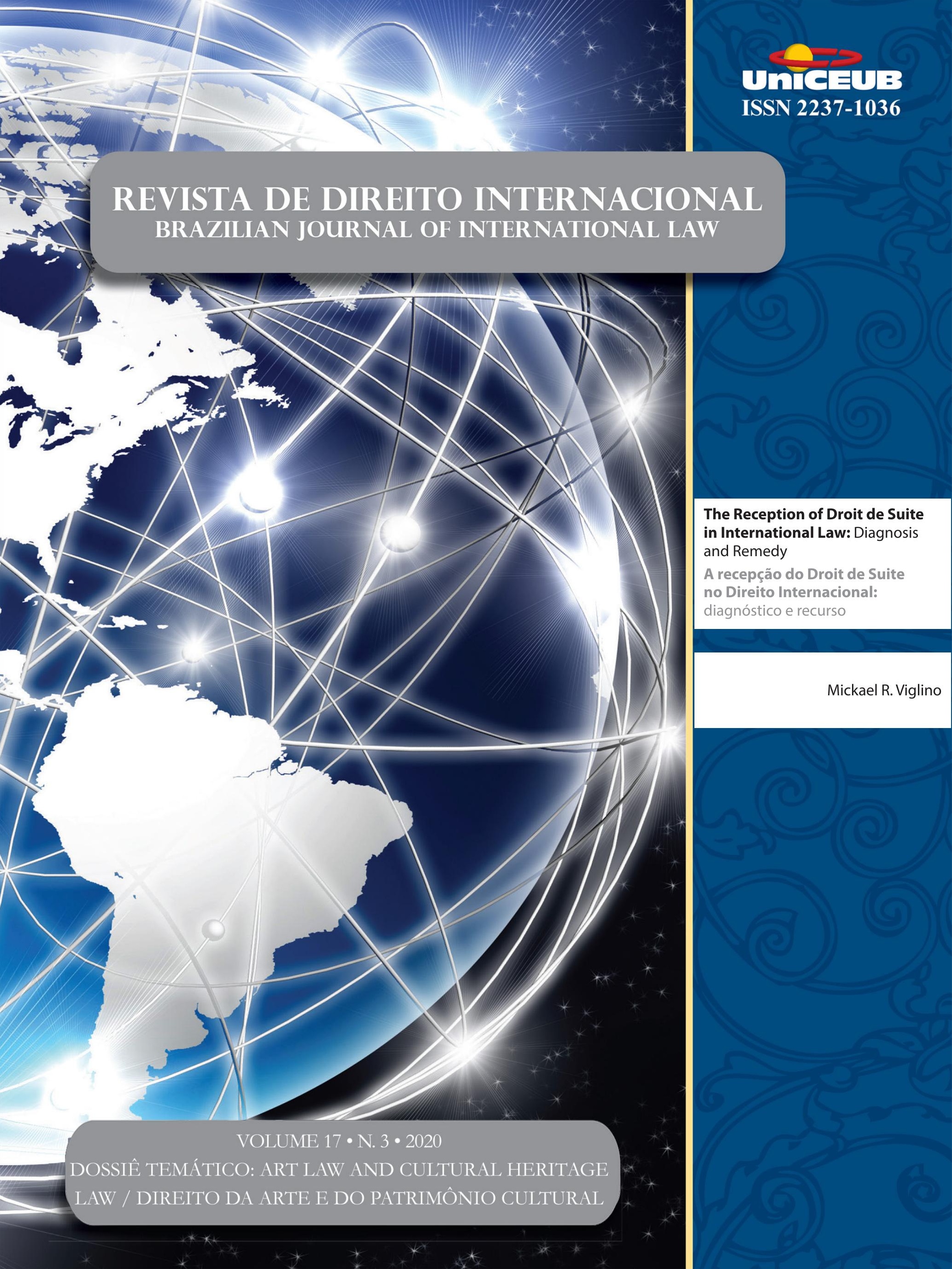




\section{Sumário}

EDITORIAL .20

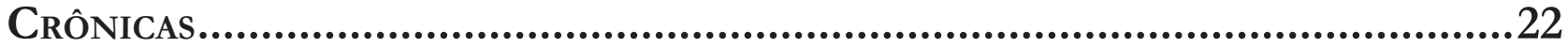

O COSTUME INTERNACIONAL COMO REFORÇO DA OBJEÇÃO BRASILEIRA À CLÁUSULA DO TRATAMENTO JUSTO E EQUITATIVO .24

Leonardo Vieira Arruda Achtschin

O PROCESSO LEGISLATIVO COMO GARANTIA PARA A OBTENÇÃo DO CONSENTIMENTO PRÉVIO DAS COMUnidades quilombolas de AlCÂNTARa

Gabriel de Oliveira Borba

Dossiê temático: Art Law and Cultural Heritage law / Direito da Arte e do Patrimônio cultural - Panorama Geral

Peoples' heritage or States' heritage? sovereignty in the UNESCO mechanism for THE SAFEGUARDING OF INTANGIBLE CULTURAL HERITAGE.

Aliki Gkana

The IMPACT OF THE UNESCO AND UNIDROIT CONVENTIONS AND THE EU DIRECTIVES ON THE INTERNATIONAL ART MARKET: AN ANALYSIS FIFTY YEARS AFTER THE INTRODUCTION OF THE OBLIGATION TO RETURN STOLEN OR ILLEGALLY EXPORTED CULTURAL GOODS 61

Geo Magri

Três pautas em destaque na agenda de diversidade Cultural da Unesco: Ambiente digiTAL, TRATAMENTO PREFERENCIAL E PARTICIPAÇÃO DA SOCIEDADE CIVIL............................76

Danilo Júnior de Oliveira, Maria Carolina Vasconcelos Oliveira e Ana Paula do Val

A 100 YEARS INSTITUTIONALIZED CULTURAL HERITAGE PROTECTION: FROM THE INSTITUTIONALIZED INTERNATIONAL COOPÉRATION INTELLECTUELLE TO THE HUMAN RIGHT TO CULTURAL HERITAGE

Lando Kirchmair 


\section{Aspectos Metodológicos do Direito da Arte e do Patrimônio}

Cultural

A proteção do PATrimônio CULTURAL EM NOVAS PERSPECTIVAS: ESTUdo COMPARAdo ENTRE A Kulturgutschutzgesetz e a Holocaust Expropriated Art Recovery Act of 2016.....111 Ardyllis Alves Soares

ArT-RELATED DispUTES AND ADR METHODS 127 Maria Beatrice Deli e Veronica Proietti

Due Diligence in Art Law and Cultural Heritage Law 150 Lisiane Feiten Wingert Ody

The Reception of Droit de Suite in International Law: Diagnosis and Remedy .... 170 Mickael R. Viglino

Direito da Arte e do Patrimônio Cultural: do Regional ao Local ....... 188

Câmara Cascudo e o legal Design - A Visualidade do Direito entre Provincianismo e GlobalizaÇão 190 Marcilio Toscano Franca Filho

A política da União Europeia no turismo: O turismo cultural e a sustentabilidade do PATRIMONNIO INDUSTRIAL PARA INTEGRAÇÃO DO BLOCO EUROPEU

Maraluce Maria Custódio e Fernando Barotti dos Santos

Diálogo entre la Corte Interamericana de Derechos Humanos y el Tribunal Europeo de Derechos Humanos en torno al Derecho humano a la identidad cultural..223 Juan Jorge Faundes

Digital ART AND THE BELT AND ROAD INITIATIVE: CHALLENGES AND OPPORTUNITIES 257 Dan Wei e Ângelo Rafael

Policing heritage crime in Latin America. .275 Naomi Oosterman e Donna Yates 
The principles of Cultural Heritage Law based on the Polish Law as an example.292 Małgorzata Joanna Węgrzak e Kamil Zeidler

Heritage Protection in INTERNATIONAL LAw AND NATIONAL LAW: INSIGHTS INTO THE CASE OF VIETNAM

Yen Thi Hong Nguyen e Dung Phuong Nguyen

THE APPROPRIATION OF THE CARIOCA INTANGIBLE CULTURAL HERITAGE BY AN ENTREPRENEURIAL LOGIC

Mário Ferreira de Pragmácio Telles

A Propósito del CARÁcter UNIVERSAL DEL aCCESO A LA CULTURA EN INTERNET: UN ANÁlisis DESDE EL PRISMA INTERNACIONAL Y LA EXPERIENCIA DEL ORDENAMIENTO JURÍDICO CUBANO 344 Janny Carrasco Medina

Direito Humanitário e Arte

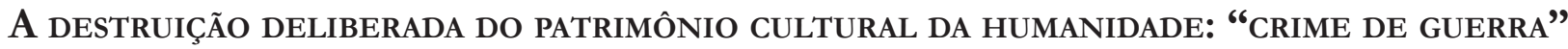
OU "CRIME CONTRA A HUMANIDADE"? Juliette Robichez

Protection OF CULTURAL PROPERTY UNDER INTERNATIONAL HUMANITARIAN LAW: EMERGING TRENDS

Niteesh Kumar Upadhyay e Mahak Rathee

Direito do Mar/Marítimo e Arte.

The underwater Cultural heritage Regime: SOME PROBlems AND POSSible SOlutions. 412 Elina Moustaira

El ROL DEL DERECHO EN LA CONSTRUCCIÓN DEL PATRIMONIO CULTURAL SUBACUÁTICO: APRECiaciones a partirdel estudio del CASo de la Corbeta Inglesa SwifT en Argentina .. 424 Norma Elizabeth Levrand e Nadia Bressan Bernhardt 
INDIGENOUS REFUGEES AND CULTURAL EROSION: POSSIBILITIES AND LIMITS OF INTERNATIONAL REFUGEE AND INDIGENOUS PEOPLES LAW IN THE PROTECTION OF INDIGENOUS CULTURAL EXPRESSIONS RELATED TO TRADITIONAL LAND AND NATIVE LANGUAGE. .440 Rickson Rios Figueira

O RETRATO DE EDMOND BELAMY E A INTERFACE ENTRE ARTE E INTELIGENCIA ARTIFICIAL: POR UMA NOVA DEFINIÇÃo DE AUTORIA E DIREITOS DE PROPRIEDADE INTELECTUAL

Marla Meneses do Amaral Leite Mangiolardo, Patrícia Silva de Almeida e Jonathan Barros Vita

Argumentative aspects of Declaration on the Importance and Value of Universal Museums (2002) 479

Agnieszka Plata

A DestinaÇão dos bens CUlturais EM PROCESSOS PENAIS: A ARTE COMO REPARAÇÃo COLETIVA 488

Inês Virgínia Prado Soares e Otavio Venturini

A Justiça de Pieter Bruegel: direito, violência e a venda nos (nossos) olhos. .501 Rafael Lazzarotto Simioni e Cícero Krupp

Artigos Sobre outros temas

DEVERES INTERNACIONAIS E OBRIGAÇÕES SOCIOAMBIENTAIS PARA EMPRESAS MULTI E TRANSNACIONAIS

Luísa Cortat Simonetti Gonçalves e Adriano Sant'Ana Pedra

Maternidade por substituição: perspectivas da ConferênCia da Haia e suas potenciais INFLUÊNCIAS NO REGRAMENTO BRASILEIRO

Tatiana de A. F. R. Cardoso Squeff e Fernanda Rezende Martins

EL (LARGO) CAMINO DE RECONOCIMIENTO Y EJECUCIÓN DE LAUDOS ARBITRALES DE INVERSIÓN

Thiago Paluma, Ivette Esis e Gabriel Briceño 
A INTERPRETAÇÃo EVOLUTIVA DA CONVENÇÃo AMERICANA SOBRE DiREITOS HUMANOS: UMA REVISÃO DOCUMENTAL DO PERÍODO 1988-2018

Breno Baía Magalhães

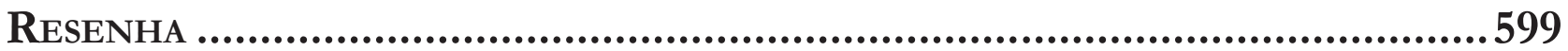

Autonomous Weapons Systems and InTERnATIONAL LAw: A STUDY ON HUMAN-MACHINE INTERACTIONS IN ETHICALLY AND LEGALLY SENSITIVE DOMAINS

Aziz Tuffi Saliba e Lutiana Valadares Fernandes Barbosa 


\title{
The Reception of Droit de Suite in International Law: Diagnosis and Remedy*
}

\author{
A recepção do Droit de Suite no Direito \\ Internacional: diagnóstico e recurso
}

Mickael R. Viglino**

The works of creators enrich our world in all senses of the word. They elevate our human experience and create prosperity for many. But the creator cannot live on air alone and his ability to create must be protected. Creators share their gift with the world, so it is only fair that those who make money from their works share a portion of this wealth with the creator.

Ousmane Sow, sculptor. ${ }^{1}$

\begin{abstract}
Droit de suite, the right for artists to receive an interest in each resale of their original artworks, commemorates one century of existence this year but remains highly hypothetical for many artists worldwide. This article addresses the reasons for this situation and proposes possible solutions by using a comparative law approach. An analysis of international (Berne Convention) and national regulations (Australia and, especially, Brazil) shows that the lack of universality and operationality of the resale royalty right is a consequence of choices made by the Berne Union in 1948. Mainly, the absence of obligation for Member States to implement it and the broad margin left to them that fosters the multiplication of national peculiarities. An amendment of article 14ter of the Berne Convention seems necessary. The World Intellectual Property Organization (WIPO) may refer to national and regional experiences - in particular, the European Union Directive 2001/84/EC of 27 September 2001 - as well as existing researches, in the current discussions on the topic, and ensure that visual artists do get a higher and fairer economic return on their work, just as other artists.
\end{abstract}

Keywords: Droit de suite. Visual art. Copyright. Berne Union. International law.

* Recebido em 15/08/2020

Aprovado em 26/03/2021

** Master's degree in business law from the University Paris II - Panthéon Assas (France), and Juris Doctor in Business Law and International Law from the University Jean Moulin Lyon III (France). Lawyer registered in France with the Barreau de Paris and in Brazil with Ordem dos Advogados do Brasil, section of Rio de Janeiro. Former visiting professor Fundação Getúlio Vargas - FGV-Rio (Brazil), for the International Program in Business, author of legal publications in France and Brazil.

E-mail: mickael.viglino@gmail.com

\section{Resumo}

Droit de suite, o direito de os artistas receberem um valor em cada revenda de suas obras originais, comemora um século de existência este ano, mas permanece altamente hipotético para muitos artistas em todo o mundo.

\footnotetext{
Ousmane Sow is also the former Vice President of the International Confederation of Societies of Authors and Composers-CISAC. Quoted by FERRY-FALL, Marie-Anne. The resale right in France. Presentation at the WIPO/SCCR International Conference on Artist's Resale Right, Geneva, Apr. 2017.
} 
Este artigo aborda as razões para esta situação e propõe possíveis soluções usando uma abordagem de direito comparado. Uma análise das regulamentações internacionais (Convenção de Berna) e nacionais (Austrália e Brasil) mostra que a falta de universalidade e operacionalidade do direito de royalties de revenda é uma consequência das escolhas feitas pela União de Berna em 1948. Principalmente, a ausência de obrigação do Membro Estados para implementá-la e a ampla margem que lhes resta favorece a multiplicação das peculiaridades nacionais. Parece necessária uma emenda ao artigo 14 da Convenção de Berna. A Organização Mundial de Propriedade Intelectual-OMPI pode se referir a experiências nacionais e regionais, bem como pesquisas existentes, para acelerar o ritmo das discussões atuais sobre o tema e garantir que os artistas finalmente se beneficiem de forma homogênea de um direito ao valor criado em torno de seu trabalho.

Palavras-chave: Droit de Suite; arte visual; copyright; União de Berna; DIreito Internacional

\section{Introducing the Droit de Suite}

As the droit de suite has just commemorated its first hundred years of existence since it was first enacted in France in 1920, one may hope that the next step be its universalization and effectivity. It would be the recognition of a legitimate participation of visual artists in the creation of economic value around their works. Hope there is, as well as significant obstacles.

Droit de suite, or resale right, or resale royalty right, is basically the "the right of visual artists to a percentage share in the proceeds of the resale of their works of art on the art market". ${ }^{2}$ It is specific to the secondary market - in opposition to the first market where artworks are sold for the very first time by authors themselves or their dealers - and usually applies only to sales involving art market professionals (auction house, art gallery, or art dealer), as private sales are harder to trace. The rationale behind it is mostly economic justice: it is the only way for visual artists to benefit from the valuation of their work over the years, especially considering the low prices of sale at the beginning of the artists' careers. It also works as a compensation for the specificity of

PFENNIG, Gerhard. The resale right of artists (droit de suite). Copyright Bulletin, v. 31, n. 3, p. 20, Jul./Sep. 1997. p. 20. visual art on the market, which provides for relatively reduced financial returns compared to other forms of art - especially music. ${ }^{3}$ In this sense, the following data regarding France, its country of origin, is revealing of the importance of the mechanism for visual artists:

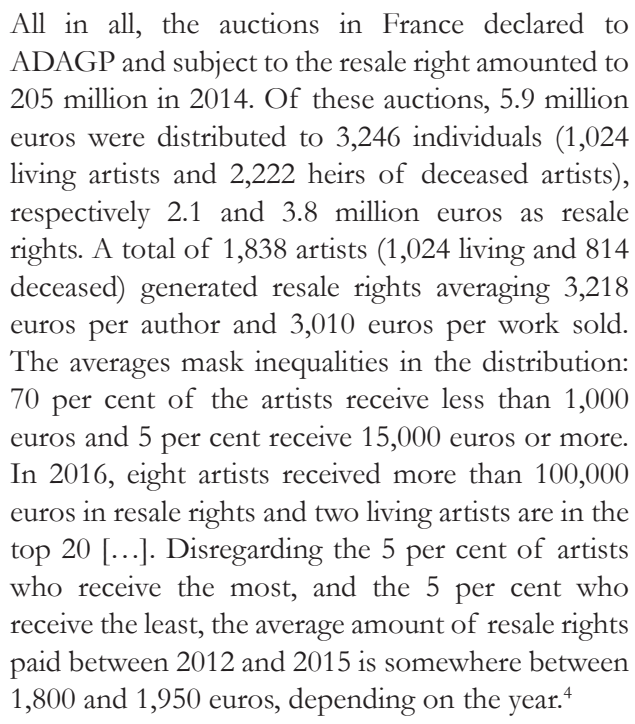

Legally, the droit de suite is a copyright with a little twist. ${ }^{5}$ Following the civil law tradition, copyrights - or droits d'auteur - are divided into economic rights - such as the exclusive right of the authors to use, enjoy (interest in possession) and dispose of their work, as well as authorize any use thereof - and moral rights - including the right of authors to claim authorship and have their names mentioned when using their works, the right to ensure the integrity of their works, and the right to withdraw their works from circulation or suspend any form of use already authorized, when it implies an affront to their reputation and image. ${ }^{6}$ Whereas econo-

While musicians, composers or writers receive a financial interest throughout the economic life of their works, visual artists may only sell their work once; then, without a resale right scheme, each new sale of the work only benefits the seller and art market professionals involved in the transaction. See MACKAY, Erin. Australian visual artists: joining the resale rights arena. Indigenous Law Bulletin, v. 7, n. 5, p. 2, 2008. Available at: http://www.austlii.edu.au/cgi-bin/ viewdoc/au/journals/IndigLawB/2008/. Last access: 21 Mar. 2021.

FARCHY, Joëlle; GRADDY, Kathryn. The economic implications of the artist's resale right. Geneva, 28 Apr. 2017. WIPO. Document SCCR/35/7, 2017. p. 17.

5 SILVA FILHO, Artur Marques da. Conteúdo dos direitos do autor. Revista dos Tribunais, v. 806, p. 11-27, dez. 2002. Specifically chapter 7 on other copyrights.

6 See, for instance, ABRÃO, Eliane Yachouh. Direitos autorais: conceito, violações e prova. Revista do Instituto dos Advogados de São Paulo, v. 27, p. 107-121, jan./jun. 2011. For a deeper analysis of the nature of intellectual property rights, and a distinction between the civil law and common law perspectives of copyright, see also ASCENSÃO, José Oliveira. A pretensa "propriedade" intelectual. Dout- 
mic rights are disposable and temporary, moral rights are inalienable, non-renounceable (they cannot be subject to an advance waiver), and permanent. The resale royalty right is precisely in-between these two categories: it is an economic right that is temporary (usually the life of the author and up to seventy years from his/ her death), inalienable and non-renounceable; it is an economic right that is extracted from the dynamics of the market so that artists may not be pressured to renounce to it by affluent art dealers and collectors, or simply out of the need of money. This makes it an hybrid copyright, an economic right with characteristics of a moral right.

Droit de suite is a legitimate object of international law since 1948, when it was included in the 1886 Berne Convention for the Protection of Literary and Artistic Works at the occasion of the Brussels' revision. At the time though, for lack of consensus, states parties only agreed on an optional right, as will be further explained in the first part of this paper. Although not an obligation under the Convention, the resale right is currently recognized by more than eighty countries, including all European Union member states, countries from all five continents, and civil law and common law systems. ${ }^{7}$ Yet, despite its apparent success, important art markets still resist - such as, for instance, the reluctance of the delegations of the United States of America and Japan at the at the World Intellectual Property Organization (WIPO), which will be further detailed below - while other countries that formally recognize it still lack the implementing regulations necessary to its effectivity, like Brazil. Therefore, resale royalties only apply to transactions realized in countries providing for, and effectively implementing it, subject to local laws, so that much remains to be done before artists worldwide may effectively rely on this source of income and financial recognition from their work.

These issues regarding the effectivity and generalization of the resale right are being discussed at the international level, in particular, at WIPO's Standing Committee on Copyright and Related Rights (SCCR).

rinas Essenciais de Direito Empresarial, v. 1, p. 1283-1306, dez. 2010. (in particular, chapters 5 and 9).

According to the count made by the International Confederation of Societies of Authors and Composers (CISAC), the world's leading network of authors' societies. Available at: https://www.cisac. org/services/policy/visual-artists-resale-right. Last access: 20 Mar. 2020 .
In December 2015, the delegations of Senegal and Congo submitted a proposal to include the resale right in the agenda of future work of the Committee, observing that:

2. Under Article 14ter, paragraph (2) this right is subject to the requirement of reciprocity and "to the extent permitted by the country where this protection is claimed". As a result, the existence and level of protection with regard to the resale right varies from one country to another and depends upon the nationality of the author or his/her place of residence. ${ }^{8}$

The year 2017 stood out as a prolific year for resale right, with an international conference organized in Geneva that presented good practices and experiences, and the publication of a very positive report on the economic implications of the resale right. ' Since then, however, not much has happened, and the inertia which often weighs on the functioning of international institutions seems to be at work. The damages caused by this inertia are all the more obvious in the current context of a global pandemic, where visual artists are at home, many of them with no income and concrete perspectives, while auctions houses and international art fairs do online business as usual, while collectors resell artworks to make some extra cash, and investors buy artworks as investment as the financial markets are especially unpredictable. Is there any good reason for artists not to take their own little share of this value created from their work? Taking the opportunity of these ongoing multilateral debates and a fairly well-spread enthusiasm, this paper seeks to make a diagnosis of the resale right today, identify the causes for its sclerosis, and propose remedies. The starting point of the present reflection is the personal observation of the author that droit de suite is not actually functioning in his country of residence, Brazil, although it legally exist since 1973. This paper aims at trying to understand what, in national and international norms, impedes the resale right from being truly effective, and identify possible solutions. To do so, the first step will be to analyze the reception of the droit de suite at the international level: how it was conceived in 1948 and how it framed the current multilateral discus-

8 WIPO. Standing Committee on Copyright and Related Rights. Document SCCR/31//5. 31 st Session, Geneva, Dec. 7 to 11, 2015. These two countries had first addressed the issue in April 2014 and met positive reactions from other delegations.

9 FARCHY, Joëlle; GRADDY, Kathryn. The economic implications of the artist's resale right. Geneva, 28 Apr. 2017. WIPO. Document SCCR/35/7, 2017. 
sions at the WIPO (II). Then, the second step will be to show how this international framework has shaped a multifaceted situation at the national level, leading to a droit de suite that is all but homogenic (III). This will be made through two opposite examples: Brazil, which may stand as an example not-to-follow for its lack of efficiency and transparency of the whole mechanism; and Australia, which, on the contrary, seems to have successfully implemented the resale royalty right in 2010 and is referred to in the works of the WIPO as an example to follow. Finally, the third step will be to propose possible solutions to remedy the lack of effectivity of the resale right, using the experience of the European Union and a comparative work from the Executive Committee of the Berne Union and the Secretariat of UNESCO (IV). By using an analytical and comparative approach of relevant norms and national experiences, this paper will try and spot the elements of the droit de suite that are essential to its effectivity, and that should be central both in the multilateral negotiations and for national regulations. The findings of this paper may be useful both to national delegations at WIPO trying to push the agenda on droit de suite and to national regulators. Opposite views exist on the appropriateness of the resale right and its effects on artists and the art market. This work will not address this issue, and will assume that the droit de suite is not in itself an obstacle to the functioning of the art market. ${ }^{10}$

\section{The initial missteps of the Berne Convention}

The 2017 Report on the economic implications of the resale right explains that even though the introduction of the resale right in the Berne Convention as early as 1948 may suggest "a certain consensus on the subject; in fact, this is only a very vague acknowledgement, leaving a wide margin of maneuver for national legislation. This explains the diversity, or indeed confusion, regarding the implementation of the resale right in na-

\footnotetext{
10 For materials with arguments from both sides, see the various contributions to the public inquiry made by the U.S. Copyright Office of the Library of Congress in 2012, "on the means by which visual artists exploit their works under existing law as well as the issues and obstacles that may be encountered when considering a federal resale royalty right in the United States". Available at: https://www.copyright.gov/docs/resaleroyalty/. Last access: 11 Aug. 2020.
}

tional legislation". ${ }^{11}$ From this initial observation, this section will proceed to an analysis of how international law molded the resale right into a secondary right (A) left greatly to the discretion of national legislations (B).

\subsection{Droit de Suite as a secondary right in international law}

When the resale right was introduced into the Berne Convention in 1948, the member States decided to depart from the central principle that permeates the Convention until today: equal treatment. According to this principle, all member countries of the Berne Union shall treat equally their nationals and the nationals of other member countries. Back then, only very few countries had enacted the resale right in their national legislations, so that negotiations for a compulsory droit de suite would not have led anywhere. Instead, the members of the Berne Union agreed on another mechanism: reciprocity. The droit de suite was finally approved under the following terms:

Article $14^{\text {ter }}$

["Droit de suite" in Works of Art and Manuscripts:

1. Right to an interest in resales; 2. Applicable law; 3. Procedure]

(1) The author, or after his death the persons or institutions authorized by national legislation, shall, with respect to original works of art and original manuscripts of writers and composers, enjoy the inalienable right to an interest in any sale of the work subsequent to the first transfer by the author of the work.

(2) The protection provided by the preceding paragraph may be claimed in a country of the Union only if legislation in the country to which the author belongs so permits, and to the extent permitted by the country where this protection is claimed.

(3) The procedure for collection and the amounts shall be matters for determination by national legislation.

The first paragraph lays the foundations of the authors' inalienable right to receive an interest in any resale of their works; then the second paragraph substantially limits its scope: to apply to a given transaction, this inalienable right must exist in the domestic laws of both

${ }_{11}$ FARCHY, Joëlle; GRADDY, Kathryn. The economic implications of the artist's resale right. Geneva, 28 Apr. 2017. WIPO. Document SCCR/35/7, 2017. p. 16. 
the member country of origin of the author and the member country where the protection is claimed. Interestingly, the ultimate criterion for an artist claiming the entitlement to the resale royalty is his/her nationality, whereas the whole Convention is based on the origin of the artwork. In doing so, the Convention virtually impedes that an artist ever enjoys a more favorable treatment than in his/her own country.

This same approach was followed by the Model Law on Copyright for Developing Countries (known as the Tunis Model Law). Adopted by a Committee of Governmental Experts convened by the Tunisian Government in Tunis from February $23^{\text {rd }}$ to March $2^{\text {nd }}, 1976$, with the assistance of the UNESCO and the WIPO, this model law includes a provision on the resale right. ${ }^{12}$ The Model Law was designed to help countries that wished to adhere to the Berne Convention to adopt domestic copyright laws compliant with the Convention, which is a prior condition. The provision on the resale right reads:

\section{SECTION $4^{\text {bis }}$}

"Droit de suite"

(1) Notwithstanding any assignment of the original work, the authors of graphic and three-dimensional works [and manuscripts] shall have an inalienable right to a share in the proceeds of any sale of that work [and manuscripts] by public auction or through a dealer, whatever the methods used by the latter to carry out the operation.

(2) The foregoing shall not apply to architectural works or works of applied art.

(3) The conditions of the exercise of this right shall be determined by regulations to be issued by the competent authority.

For countries that would choose to use the Model Law as national copyright regulation, this section of is expressly optional. This means that they may disregard this provision on droit de suite and still join the Berne Union, which may not be the case for other provisions deemed essential to the Union. In countries that would recognize the resale right, the same principle of reciprocity as in the Berne Convention would in principle apply, based on the nationality (or residence) of the artist and the place of the resale.

This section $4^{\text {bis }}$ meaningfully comes after Section 4 on economic rights and before section 5 on moral

12 UNESCO and WIPO. Tunis model law on copyright. Copyright, n. 7-8, July/Aug. 1976. p. 165. rights, showing the hybrid nature of the droit de suite. It is, like Article 14ter of the Berne Convention, rather concise, and leaves the conditions of its exercise to national implementing regulations. Regardless of the actual influence of the Model Law on national copyright legislations, this text adds to the idea that droit de suite was neither a consensus nor a priority during the early years that shaped copyright at the international level.

\subsection{Droit de Suite as a broad concept left to the States}

As regards the substance of the resale right, the Berne Convention leaves great latitude to domestic laws, specifically regarding the procedure for collection, the amounts, and the persons or institutions to whom the right may be assigned causa mortis. It barely addresses the very essence of the right, i.e., the subjects (the author, or, after his/her death, authorized persons or institutions), the object (original works of art and original manuscripts of writers and composers), and the extent of the right itself (any sale of the work subsequent to the first transfer by the author). Most importantly, it provides for the main trait of the right: it is, contrary to the other economic rights of authors, inalienable. In doing so, the Convention commands that any member state who shall decide to implement the resale right in their national legislations to conceive it as a hybrid copyright.

The margin left to domestic legislations regards important features of the resale right. For instance, the procedure for collection of the respective amounts may be left to authors themselves or attributed to collective entities with this specific purpose; it may provide for derogatory procedures and formalities aimed at facilitating its collection (access to information, reporting obligations from the professional sellers), or simply resort to common laws. The financial burden may also greatly vary from one country to another, with distinct rates and basis of application (the full resale price or just the capital gain), as well as administrative costs for art market professionals. This last aspect, in particular, has direct effects on the relative competitivity of national art markets compared to the others, and is commonly put forward as much by opponents of the resale right - in favor of its suppression - as by its supporters - advocating for its universalization. ${ }^{13}$ The situation of

\footnotetext{
13 PFENNIG, Gerhard. The resale right of artists (droit de suite).
} 
artists may therefore greatly vary from one country to the other, depending on their nationalities, domicile and the place of the resale.

The Tunis Model Law shows two distinctive features. First, the object of the resale right is more specifically defined than in the Berne Convention, which generally refers to "original works of art and original manuscripts of writers and composers". The resale right should apply to graphic and three-dimensional works, at the exclusion of architectural works or works of applied art, and may extend to manuscripts. Second, and foremost, the Model Law provides that the right applies to any sale "by public auction or through a dealer", where the Convention refers to "any sale" without consideration to the identity of the seller. This is a key issue in the effectivity of the resale right, as it is not possible, in practice, to monitor and control all transfers of works of art between individuals acting privately (as non-professionals).

If this discretion left to national legislations finds justifications - the lack of consensus and the too many implementing modalities, for instance - it can also be an obstacle to the effectivity of the resale royalty right. For instance, the concept of artwork is deeply rooted in cultural premises, and if general lines may be drawn that are shared by most countries, it would be merely impossible to get to a consensus on a comprehensive definition of the term at the international level. For this reason, it seems a wise choice to agree in the Convention on a broad definition and leave the details to national legislatures and courts. On the contrary, the amount of the royalty (the rate and the basis for calculation) is the main element of distortion of competition in between national art markets, so that it is not enough to make the droit de suite compulsory if countries remain entirely free to set the applicable rate. It would reproduce at another level the same distortions that may exist between

Copyright Bulletin, v. 31, n. 3, p. 20, Jul./Sep. 1997.: "Now that the imposition of droit de suite is becoming a factor on the art market, there is to the same degree an increasing interest in shifting markets and the relocation of art market operations to countries that do not recognize this right, thus creating an imbalance between the markets which could negatively impact art sales in countries that recognize droit de suite. [...] However, in evaluating the droit de suite one should not overlook the fact that the art market is subject to a whole range of other influences which develop independently from copyright law, such as, for instance, the economic situation in large trading markets such as the United States of America, taxation and the general cost situation, in particular with regard to auction markets as a whole." countries that have and countries that do not have the resale right. The solution is not necessarily in a unified compulsory rate, but a margin that would allow a certain equivalence of the rates regardless of the country where the sale is realized.

Therefore, two choices were made in the Berne Convention that have shaped the resale right until today. On the one side, its non-compulsory nature and the principle of reciprocity; they have narrowed the effectivity of the resale right and created obstacles to its application, with distinct categories of authors that may or may not benefit from it depending on their nationality or domicile. On the other side, the freedom left to the member States for implementing this mechanism nationally has hampered any aspiration to homogeneity between national legislations.

The Berne Convention and, to a lesser extent, the Tunis Model Law are the only means of international law dealing with the resale right. As briefly shown above, they do not suffice to guarantee a fair and equal treatment among visual artists worldwide. Following the promising events of 2017 mentioned in introduction, the Chair of WIPO's Standing Committee on Copyright and Related Rights (SCCR) suggested in June 2018 the setting up of a task force of experts to report back to Committee regarding the practical elements of the resale royalty right. ${ }^{14}$ If this may seem a positive step, the minutes of the Committee session show that it comes as an alternative to making the resale right a part of the standing agenda, due to the absence of consensus among the delegations. ${ }^{15}$ Most countries and regions were in favor of the proposal from Senegal and Congo, ${ }^{16}$ but important delegations opposed it, in particular, Japan and the U.S.A. The task force was presented to the Committee in November 2018 and "will address the essential elements of an [Artist Resale Right] system which are common to most laws", in particular, the ba-

14 WIPO. Next steps on Other Matters proposed by the Chair. Document SCCR/36/4. 36 $6^{\text {th }}$ Session, Geneva, May 28 to June 1, 2018. 15 WIPO. Draft Report from the Secretariat. Document SCCR/36/8. 36 $6^{\text {th }}$ Session, Geneva, May 28 to June 1, 2018. p. 55.

16 Brazil, for example, "On making the resale right a standing item on the SCCR agenda, the topic merited it. The resale right was a copyright issue which included complex technical issues. Moving it from the list of other topics to a self standing agenda item would facilitate a richer discussion without affecting the other very important discussions that the Committee had been having such as on broadcast, as referred to by the Delegation of Japan." (WIPO. Draft Report from the Secretariat. Document SCCR/36/8.36 $6^{\text {th }}$ Session, Geneva, May 28 to June 1, 2018. p. 55, 58). 
sis of calculation, the works and transaction covered, and the mode of collection, distribution and management of the right. ${ }^{17}$ The U.S. delegation reiterated that the discussion on the resale right should remain in the "Other Matters" agenda, and that "the task force was best suited as a fact-finding body" - words that reveal a clear aim to reduce the role of the working group. ${ }^{18}$ This point was further stressed during the $38^{\text {th }}$ Session of the Committee, in April 2019, when the Secretariat, reporting on the composition and first meeting of the task force, declared:

\begin{abstract}
As regards the proceedings, the mandate of the task force was not to address and solve the political issues raised by the artist resale right but to rather consider the practical issues of that right. To that end, experts from different angles and different interests were invited in order to enrich the discussions and to try to find some common ground for that project as well as to enrich the SCCR. ${ }^{19}$
\end{abstract}

The last meeting of the Committee, in October 2019, did not show any real progress. The African Group recalled that the artist's resale right had been a longstanding issue and "had gained strong support from a large majority of members across all regions", and the delegation of the European Union called that "should the SCCR agenda be expanded to cover additional items in the future, priority should be given to the resale right over any other topic". ${ }^{20}$ Yet, the delegation of the U.S.A. is "not ready to accept it as a part of the permanent agenda for SCCR and suggested that it stays under the other matters items on the agenda", ${ }^{21}$ so that no practical result should be expected soon. In the meantime, visual artists face very different realities from one country to the other.

\section{A kaleidoscope of resale rights}

The decision made in 1948 by the members of the Berne Union was basically to leave the droit de suite to

\footnotetext{
7 WIPO. Task Force on the Artist's Resale Royalty Right. Document SCCR/37/5.37 th Session, Geneva, Nov. 26 to 30, 2018.

18 WIPO. Draft Report from the Secretariat. Document SCCR/37/9.

$37^{\text {th }}$ Session, Geneva, Nov. 26 to 30, 2018. \$183.

19 WIPO. Draft Report from the Secretariat. Document SCCR/38/11. 38 $8^{\text {th }}$ Session Geneva, Apr. 1 to 5, 2019.

20 WIPO. Draft Report from the Secretariat. Document SCCR/39/8. $39^{\text {th }}$ Session, Geneva, Oct. 21 to 25, 2019. Spec. S\$ 293 and 297.

21 WIPO. Draft Report from the Secretariat. Document SCCR/39/8. $39^{\text {th }}$ Session, Geneva, Oct. 21 to 25, 2019. \$309.
}

State legislations. This has had a direct consequence in the shaping of this artists' right: an infinity of modalities and expressions among countries. If diversity in itself is not a problem, it becomes one when it constitutes an obstacle to the functioning of the right, especially in light of the principle of reciprocity provided for in the Berne Convention, and of the fact that not all such national experiences are successful. Brazil, on the one side, is a good illustration of an ineffective system, despite existing legally since 1973. Australia, on the other side, stands among the countries regularly cited as an example to follow, as shown by the works of WIPO's SCCR. The case of Australia is all the more interesting as it is a common law country, whereas one of the arguments of the opponents to droit de suite is precisely that it does not fit in the common law theory of copyright. ${ }^{22}$ Brazil and Australia also have in common the presence of indigenous communities, and the Australian resale royalty right scheme has proved positive to indigenous artists, even though it does solve the problems faced by traditional cultural expressions, nor even aims to tackle the issue. ${ }^{23}$ The purpose of the following paragraphs is not to provide an in-depth analysis of the national regulations in both countries, but rather to point out differences and similarities, and the consequences of these characteristics on the effectivity of the respective schemes. At this point, the basic question may well be: what is Brazil doing wrong that Australia understood?

\subsection{Brazil, an example not-to-follow}

Resale right was formally introduced into Brazilian law through the former Copyright Act of 1973 (Law No. 5,988/73), and confirmed in the new Copyright

\footnotetext{
22 See, for instance, BUSSEY, Alexander. The incompatibility of droit de suite with common law theories of copyright. Fordham Intellectual Property Media \& Entertainment Law Journal, n. 1063, 2013. Available at: https://ir.lawnet.fordham.edu/iplj/vol23/iss3/6. Last access: 21 Mar. 2021.

23 See, MACKAY, Erin. Australian visual artists: joining the resale rights arena. Indigenous Law Bulletin, v. 7, n. 5, p. 2, 2008. Available at: http://www.austlii.edu.au/cgi-bin/viewdoc/au/journals/In$\operatorname{digLawB} / 2008 /$. Last access: 20 Mar. 2021. This issue is not to be confused with that of protection of cultural heritage. The resale right does not aim to address the defense of traditional cultural expressions and is certainly not fit for this purpose. But it remains a possible source of income for communities that are usually excluded from the benefits of the creation of economic value through their art works. See: MACKAY, Erin. Indigenous traditional knowledge, copyright and art: shortcomings in protection and an alternative approach. UNSW Law Journal, v. 32, n. 1, 2009.
} 
Act of 1998 (Law No. 9,610/98) in the following terms:

Art. 38. The author has the non-renounceable and inalienable right to perceive five percent at least of the price increase eventually observed at the occasion of each resale of original works of art or manuscripts that he has sold.

Single paragraph. If the author should not receive such resale right at the time of the resale, the seller is considered to be the depositary of the amount that is due to him, unless the operation is carried out by an auctioneer, when the latter will be the depositary.

This provision is included into the chapter of the Copyright Act that deals with the economic rights of the authors, and not in a distinct chapter in between economic and moral rights, as in the Model Law. Yet, it is inalienable and non-renounceable for the duration of the right, i.e., the artist's lifetime and seventy years after his/her death.

Article 39 of the former Copyright Act extended the resale right to the sales of economic rights over intellectual work, and provided for an amount equivalent to $20 \%$ of the price increase, on the condition that the resale price be equivalent to at least five times the highest minimum salary then in force in Brazil. Therefore, there has not been a dramatic change in the regulation of the direito de sequencia with the enactment of the new Copyright Act, lest the substantial cut in the rate itself, from $20 \%$ to $5 \%$ of the price increase, compared to the immediately previous sale.

The first obvious characteristic is the regulation of droit de suite in Brazil is its brevity: only one single article in the Copyright Act, and no implementing regulations whatsoever. Conciseness is a quality, but in this case it is frustrating, especially considering that the Berne Convention expressly provides that "The procedure for collection and the amounts shall be matters for determination by national legislation" (Article 14ter, paragraph 3). Even in France, where droit de suite has been existing for a century and where there is consistent experience and practice, article L122-8 of the Code of Intellectual Property that provides for the right is more detailed, and complemented with a dedicated Decree No. 2007756, of 9 May 2007. In these comparative terms, the Brazilian way of legislating suggests that some critical points may be missing.

One of these lapses is precisely the procedure for collection mentioned in the Berne Convention. In the absence of provision for the collective management of the resale right, artists themselves are responsible for the collection of their royalties. Yet, the Brazilian Copyright Act does not provide for specific procedures, such as, for example, right to information for the artists or obligation to report a sale subject to the resale right by the seller or the art market professional. This aspect is key to the effectivity of the whole scheme, as observed by Prof. Dr. Gerhard Pfennig, former Executive Director of German collecting society VG Bild-Kunst and spokesperson of the Authors' Rights Initiative:

The prerequisite for the effective exercise of droit de suite is that the beneficiary artist must receive information on the sales proceedings, in particular the sales process. Experience shows that the implementation of droit de suite is to a great extent impractical if the right to demand such information is not established. ${ }^{24}$

This difficulty has already been referred to the Judiciary, but the Court of Appeals of the State of São Paulo did not show much understanding to the daughter of the Brazilian sculptor Victor Brecheret and her difficulties in identifying a possible resale subject to royalty. ${ }^{25}$ At the occasion of an exhibition of works from her father, the heiress asked the art gallery information regarding a few works and the transactions that occurred. Facing the gallery's refusal of cooperation, and in the absence of specific mechanism of access to information under the Brazilian Copyright Act, the heiress filed a request for a precautionary measure for the display of documents under the Code of Civil Procedure. This request was dismissed in first instance and in appeal, on the ground that the gallery had denied being in possession of the documents and that the plaintiff had not brought the necessary proof to the contrary. This is revealing of the obstacles to the effectivity of the resale right in the absence of implementing regulations, as common law rules may not be adequate to the structure of the art market. This was even acknowledged by one of the appellate judges who, in a dissenting opinion, recognized the legitimate interest of the heiress as well as the impossibility in which she finds herself to provide other documents in support of her action, being the role of the Judiciary to grant her the precautionary measure so that she may exercise the right she is entitled to by law.

\footnotetext{
24 See PFENNIG, Gerhard. The resale right of artists (droit de suite). Copyright Bulletin, v. 31, n. 3, p. 20, Jul./Sep. 1997.

25 SÃO PAULO. Tribunal of Justice of the State of São Paulo. Process No. 9191457-27.2007.8.26.0000, Civil Appeal (Apelação Cível)
} No. 491.027-4/5-00, decision of 26 Feb. 2008. 
Even where article 38 of the Copyright Act gives indications on specific aspects of the right, it does not necessarily show very wise. In this sense, a distinctive feature is the calculation of the royalty: the rate applies on the price increase observed at the occasion of the resale. This option is perfectly relevant if one considers that the resale royalty is the right for visual artists to participate in the increase in value of their works over time. It is certainly as relevant as considering the resale royalty as the right for artists to participate in the economic exploitation of their work, and therefore calculating the royalty based on the resale price itself. Yet, in practice, considering the price increase may not be much convenient, as it underlies the need to determine such price increase, and therefore provide for rules of calculation, in particular for determining the price of first acquisition and possible inflation over the period. ${ }^{26}$ To avoid this issue, many countries - including Australia and the Member States of the European Union - opted to refer to the resale price itself. The E.U. Directive 2001/84/ $\mathrm{EC}$ on the resale right expressly refers to this issue in its Recitals:

(20) Effective rules should be laid down based on experience already gained at national level with the resale right. It is appropriate to calculate the royalty as a percentage of the sale price and not of the increase in value of works whose original value has increased.

Therefore, in spite of the good intentions expressed by the delegation of Brazil at WIPO's Standing Committee on Copyright and Related Rights, the droit de suite remains highly ineffective nationally, ${ }^{27}$ and courts' precedents hardly help filling the regulatory gap. ${ }^{28}$ Unfor-

\footnotetext{
26 This issue was object of another judicial process involving again the daughter of Victor Brecheret, regarding another sculpture: SÃO PAULO. Tribunal of Justice of the State of São Paulo. Interlocutory Appeal (Agravo de Instrumento) No. 2072639-84.2020.8.26.0000, decision of 30 June 2020 . This decision is indicative of the difficulties encountered by beneficiaries of a resale right to evidence the price increase, as well as the apparent inexperience of the Public Prosecutor's Office on the issue. Yet, in this more recent case, Ms. Sandra Brecheret was more successful and could obtain the payment of the resale right.

${ }^{27}$ See, for example, DE-MATTIA, Fábio Maria. Droit de suite ou direito de sequência das obras intelectuais. Revista dos Tribunais, v. 741 , p. 58 , jul. 1997. The author evokes the failed attempts of the extinct National Copyright Council to implement the resale right. 28 See, as a rare example: BRASIL. Supreme Court of Justice - STJ. REsp 594.526, of 02 April 2009 (Rapporteur Luis Felipe Salomão), regarding works by Brazilian painter Portinari, whereby the Court expressly acknowledges the droit de suite as an economic right of the author, and rules in favor of its application even when the first sale of the work is realized by the artist's inheritors, after his/her death.
}

tunately, due to the absence of an entity to collectively manage and collect the resale right, there is not much public data on the reality of droit de suite in Brazil, contrary to other countries.

\subsection{Australia, a successful conversion}

Resale right came into effect in Australia in 2010, after the Resale Royalty Right for Visual Artists Act 2009 (Cth) was enacted. It is a detailed piece of legislation of over fifty sections, a meticulousness that makes sense in a common law country that has never had droit de suite before. This certainly requires education of the stakeholders for implementing new practices and mindsets. For lack of familiarity with the Australian legal system, this section will focus on the Act itself, how it defines the resale right and articulates it, as well as doctrinal analyzes, without making a study of the jurisprudence of the local courts.

The Act provides for a "right to receive resale royalty on the commercial resale of an artwork", where an artwork is "an original work of visual art that is either (a) created by the artist or artists; or (b) produced under the authority of the artist or artists" (Sections 6 and 7). The Act gives a substantial and non-limitative list of what constitutes an artwork for the purposes of the resale right, from which are specifically excluded architectural works (resale of a building, or a drawing, plan or model for a building) and manuscripts of literary, dramatic or musical works (Section 9). The Act also expressly excludes transactions "that do not involve an art market professional acting in that capacity", i.e., auctioneers, owners or operators of art galleries or museums, art dealers, and persons otherwise involved in the business of dealing in artworks (Section 8(2)(3)).

The resale royalty is payable at the rate of $5 \%$ of the sale price, precisely defined as the price paid by the buyer, including the Goods and Services Tax, excluding any buyer's premium or other tax payable on the sale. It applies when the sale price is at least AU\$1,000 (Section 10). This royalty is defined as a "debt" - avoiding any attempts to assimilate it to a tax or anything - due to the holder of the resale royalty right, that is, the artist or his/her successors in title who satisfy the residency test at the time of the resale (Section 12). The benefit of the resale royalty is, thus, based on nationality and/or residence, and includes "a national or citizen of a coun- 
try prescribed as a reciprocating country" (Section 14), which is in line with the Berne Convention. It is "absolutely inalienable" and not subject to waiver, and subsists 70 years after the artist' death. This debt is due, jointly and severally, by the seller and each person acting as art market professional and as agent for the seller, and, if there is no such agent, each person acting as art market professional and as agent for the buyer, and, if there are no such agents, the buyer him/herself (Section 20).

Australia made the choice of the collective management of the resale royalty scheme by a specialized body, and the Act brings extensive provisions on the process of collecting and the appointment and functioning of the collecting society - currently, Copyright Agency Limited. In particular, the collecting society is to publish notice on its website when it is aware of a commercial resale of an artwork; unless the holder of the resale royalty right notifies the collecting society in writing, within 21 days after such notice, that the collecting society is not to collect the resale royalty, the collecting society must use its best endeavours to collect and enforce the resale royalty (Section 23). The Act also provides for an obligation for sellers to give a notice to the collecting society within 90 days from the commercial resale (Section 28), as well as a right for the collecting society, when they have reasonable grounds to believe that a commercial resale has taken place, to request information relevant to determining the amount of any resale royalty and who is liable to make the payment (Section 29). These two provisions are subject to civil penalties.

According to the figures published by the Copyright Agency, in ten years of existence (since its start on 9 June 2010 until 15 December 2020), the resale royalty scheme has generated royalties totalling more than AU $\$ 9$ million from more than 22,300 resales, benefiting more than 2,075 artists, the majority for amounts between $\mathrm{AU} \$ 50$ and $\mathrm{AU} \$ 500 .{ }^{29} \mathrm{It}$ is all the more remarkable as the Act is not retrospective - i.e., a first sale needs to be realized after the 9 June 2010 for the resale right to apply to subsequent changes of ownership which means that a relevant portion of the sales are still out of the resale right scheme. Australia has, together with France, one of "the most developed systems of protection and modes of collection and distribution, including as regards the management of the right for

29 Copyright Agency. Available at: https://www.resaleroyalty.org. au/. Last access: 23 Mar. 2021. cross-border transactions", ${ }^{30}$ which is, again, particularly interesting considering that Australia is a common law country. ${ }^{31}$

Australia is even more relevant as a case study as it brings additional arguments and data in favor of the universalization of the resale right. Indeed, according to the same source, Aboriginal or Torres Strait Islander artists account for over $65 \%$ of the artists receiving royalties and $38 \%$ of the total royalties paid. Despite this smaller share in the amounts paid, Aboriginal or Torres Strait Islander artists represent 18 of the 50 artists who have received most money under the scheme. ${ }^{32}$ This beneficial effect on indigenous artists was mentioned on the 2017 Report on the economic implications of the resale right:

One example is the resale of Water Dreaming at Kalipinypa by indigenous artist Johnny Warangkula Tjupurrula for 486,500 dollars in July 2000, after its original purchase in the 1970s for around 150 dollars. Another event that drew attention to the issue was last year's resale of Emily Kngwarreye's work Earth's Creation for a record price of over one million dollars. ${ }^{33}$

Again, resale right is not an answer to issues of protection of cultural heritage and traditional cultural expression, which need to be addressed by specific means. But these figures bring an additional argument in favor of an effective droit de suite. Artistic production can and should constitute a source of income, and an element of recognition and emancipation of indigenous communities that are often marginalized and in a situation of dependence on local public authorities, a situation common to many countries, including Brazil. ${ }^{34}$

30 WIPO. Draft Report from the Secretariat. Document SCCR/38/11. 38 ${ }^{\text {th }}$ Session Geneva, Apr. 1 to 5, 2019. \$230.

31 For a detailed analysis of the first three years and four months of the Australian resale right scheme, including complaint from the market stakeholders, see AUSTRALIA. Department of Communication and the Arts. Post-Implementation Review: Resale Royalty Right for Visual Artists Act 2009 and the resale royalty scheme. 23 Dec. 2019. Available at: https://www.arts.gov.au/documents/ post-implementation-review-resale-royalty-right-visual-artists-act2009-and-resale-royalty-scheme. Last access: 23 Mar. 2021.

32 Copyright Agency. Available at: https://www.resaleroyalty.org. au/. Last access: 10 Aug. 2020.

33 FARCHY, Joëlle; GRADDY, Kathryn. The economic implications of the artist's resale right. Geneva, 28 Apr. 2017. WIPO. Document SCCR/35/7, 2017. p. 27.

34 See PHAM, Lan. The resale royalty right: what does it mean for indigenous artists?. Indigenous Law Bulletin, v. 7, n. 20, p. 21, 2010. Available at: http://www.austlii.edu.au/cgi-bin/viewdoc/au/journals/IndigLawB/2010/. Last access: 21 Mar. 2021. 
Droit de suite opponents usually argue that the very structure of the art market, its inherent lack of transparency, condemns the resale right mechanism to ineffectiveness. If the situation in Brazil could lead to believe that this is true, the Australian experience seems to show different - despite critics from the Australian art market professionals - and that this excuse is not satisfactory. In addition, this same argument could be used about regulations on anti-money laundering and combatting the financing of terrorism in the art market, and no one would take the risk of such a stand. From the comparison between Brazilian and Australian legislations, the key to an effective droit de suite seems to be much more in the regulations themselves than in the structure of the art market.

From the review of the international instruments and ongoing negotiations (Part II) and experiences at the national level (Part III), two observations come out: certain options in the characteristics of the resale right scheme must be made (or avoided) to ensure its effectivity nationally, and a certain homogeneity among countries is necessary to ensure that visual artists' right to a resale royalty be more or less equally guaranteed, regardless of their nationality, place of residence, and place of transaction. The framework provided by the Berne Convention does not suffice to guarantee the efficiency of the resale right scheme; more detailed implementing rules are necessary, but not just any rules, as evidenced by the choices made by the Brazilian copyright act.

\section{Looking for Remedies: Food for Though}

In a globalized art market, where transactions have occurred across borders long before the invention of the Internet, the effective enjoyment of resale royalties by artists around the world is an issue to be dealt with as part of an international agenda. As the African Group put it during the $38^{\text {th }}$ Session of the WIPO/SCCR in $2019 .:^{35}$

The African Group pointed out that the artist resale right in the Berne Convention was an optional provision as such protection was only guaranteed to countries that offered that reciprocal protection. Given the optional nature of resale royalty

35 WIPO. Draft Report from the Secretariat. Document SCCR/38/11. $38^{\text {th }}$ Session Geneva, Apr. 1 to 5, 2019. \$232. right, regimes by nearly half of the membership recognized it, but there was a need for the resale royalty right to be mandatory. The African Group supported that the resale right proposal be included on the agenda of the SCCR for the following reasons: first, to ensure that more artists receive fair remuneration for their creation and improve fairness for artists across the globalized market regardless of where they live or where their work was sold $[\ldots]$

The work of the WIPO/SCCR and the dedicated task force will be much harder than just turning compulsory Article 14ter of the Berne Convention. It will fall short if not accompanied by an improvement in the wording, more specific, leaving less space for national peculiarities. For this work, yet, the Committee and its task force will not need to start from scratch. Regarding the necessary homogeneity of the mechanism at the global level, the European Union is a good example of the level of standardization necessary for the resale royalty scheme to actually operate (A). Regarding the elements to consider when defining the core characteristics of the right, a research document from the Executive Committee of the Berne Union will prove much helpful, thirty five years after its first publication (B). This last part of the paper aims at showing how the European experience and the guidelines from the Executive Committee of the Berne Union may serve as reference to shape the resale right mechanism both at the international and at the national levels. For this reason, each deserve a thorough analysis of their relevant aspects.

\subsection{The EU as a standard for homogenization of national legislations}

The European Union may legitimately take a great role when it comes to the study of the droit de suite. Not only for historical reasons (the Australian example shows that a country does not need a century of practice to work it out well), but rather due to the Directive 2001/84/EC of the European Parliament and of the Council of 27 September 2001 on the Resale Right for the Benefit of the Author of an Original Work of Art. This regulation is the first example of compulsory resale royalty scheme at the supranational level, as well as a political stand at the international level, when Recital 7 expresses the necessity "for the European Community, in the external sphere, to open negotiations with a view to making Article 14ter of the Berne Convention 
compulsory". Indeed, if the first move at the WIPO did come from the delegations of Senegal and Congo, the EU has consistently supported this initiative. ${ }^{36}$

Formally, the experience of the European Union with Directive 2001/84/EC has a double interest. First, during the discussions on the text, it faced strong opposition from a few countries, themselves facing strong lobbying from their national art markets, such as the United Kingdom and Austria. Still, it was finally adopted, and provided for transitional periods for its implementation by national legislations, especially for countries that did not already have it. Second, back in 2011, only 11 Member States had a resale royalty scheme in their domestic legislations, and for a few of them it was only theoretical. This is promising in the context of the current discussions at WIPO, where a reasonable number of members do not recognize the droit de suite nationally and certain delegations fiercely oppose any concrete progress on the subject.

Regarding the substance of the resale royalty right, the Directive 2001/84/EC shows that if the harmonization of national legislations is necessary to the effective operation of the scheme, a total identity is not. For the resale right to work efficiently for all the stakeholders (including artists, collectors, professionals of the art markets, and the States), national regulations need to share certain characteristics, which does not mean they need to be identical. In this sense, the Recitals of the Directive 2001/84/EC:

\begin{abstract}
(9) The resale right is currently provided for by the domestic legislation of a majority of Member States. Such laws, where they exist, display certain differences, notably as regards the works covered, those entitled to receive royalties, the rate applied, the transactions subject to payment of a royalty, and the basis on which these are calculated. [...]

(13) Existing differences between laws should be eliminated where they have a distorting effect on the functioning of the internal market, and the emergence of any new differences of that kind should be prevented. There is no need to eliminate, or prevent the emergence of, differences which cannot be expected to affect the functioning of the internal market.
\end{abstract}

\footnotetext{
36 "The Delegation [of the EU] recalled that the proposal to include the topic in the agenda of the SCCR began during SCCR 27 and was tabled at SCCR 31. For that reason, the European Union believed that should the SCCR agenda be expanded to cover additional items in the future, priority should be given to the resale right over any other topic.", WIPO. Draft Report from the Secretariat.

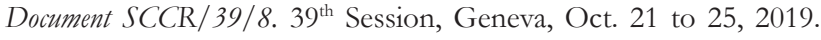
$\$ 297$.
}

The WIPO/SCCR may use a similar criterion to distinguish the elements that need to be standardized and those that can be left to national legislations. Instead of the distorting effect on the functioning of the internal market, the reference could be the functioning of the globalized art market and how to ensure that the implementation of a compulsory droit de suite does not create competitive obstacles between States.

For instance, rates are an important element for the application of the resale right: "The effective functioning of the internal market in works of modern and contemporary art requires the fixing of uniform rates to the widest possible extent" (Recital 23). This because "It is important to reduce the risk of sales relocating and of the circumvention of the Community rules on the resale right" (Recital 24). Therefore, the Directive 2001/84/EC provides for a precise set of progressive rates, from $4 \%$ for the portion of the sale price up to EUR 50,000 , to $0,25 \%$ for the portion of the sale price exceeding EUR 500,000, with a cap of EUR 12,500 in royalties, leaving little margin to the Member States for national adjustments.

Unlike rates, Member States are given more latitude as to the person by whom the royalty is payable (Recital 25) and who should receive it, with due regard to the principle of subsidiarity (Recital 27). The Court of Justice of the European Union has already had the opportunity to assert this principle. In a judgment from $2010,{ }^{37}$ the Court ruled on the possibility for Member States to allow or not the passing of the resale royalty right to successors in title, upon the death of the artist. This case dealt with royalties due on sales realized in France of works from Spanish painter Salvador Dalí; whereas the Spanish State is sole legatee of all the rights on the painter's works, including resale right, in line with Spanish law, French law expressly reserves the resale right to heirs, to the exclusion of legatees or successors in title. In this context, the Court of Justice acknowledged that:

30. As regards the second objective [to put an end to the distortions of competition on the market in art], it was considered indispensable to provide for harmonisation concerning works of art and sales

CJUE (Third Chamber), Case C-518/08 (Fundación Gala-Salvador Dalí e Visual Entidad de Gestión de Artistas Plásticos (VEGAP) V. Société des Auteurs dans les Arts Graphiques et Plastiques (ADAGP) e.a.), reference for a preliminary ruling under Article 234 EC from the Tribunal de Grande Instance de Paris (France), judgment of 15 April 2010. 
affected by the resale right as well as the basis for and rate of the royalty. As is clear from recital 9 in the preamble to Directive 2001/84, the European Union legislature sought to resolve a situation in which sales of works of art were concentrated in Member States in which the resale right was not applied, or where it was at a lower rate than that in force in other Member States, to the detriment of auction houses or art dealers based in the territory of the latter Member States.

31. [...] Therefore, as is apparent from recitals 13 and 15 in the preamble to that directive, there is no need to eliminate differences between national laws which cannot be expected to affect the functioning of the internal market and, in order to leave as much scope for national decision as possible, it is sufficient to limit the harmonisation exercise to those domestic provisions that have the most direct impact on the functioning of the internal market.

Therefore, France may legitimately reserves the benefit of the resale right to artist's heirs at law alone, just as much as Spain may open this benefit to testamentary legatees, the issue not being a question of resale right proper, but of succession and private international law, which fall beyond the scope of the Directive.

The same applies to the contractual freedom of the parties. In a case from 2015 opposing the auction house Christie's France and the French Syndicat National des Antiquaires, the Court ruled that article 1(4) of the Directive $2001 / 84 / \mathrm{EC}$, which provides that the royalty is payable by the seller, does not preclude the parties in a transaction subject to the resale right to agree that another person would finally bear such cost, so long as it "does not affect the obligations and liability which the person by whom the royalty is payable [designated as such by national law] has towards the author". ${ }^{38}$ More specifically:

28 In order to be able to provide an interpretation in the light of the silence of Directive 2001/84 in this regard [the identity of the person who must definitively bear the cost of the royalty], it is necessary to refer to the objectives pursued by the directive. On that point, although Directive $2001 / 84$ seeks, inter alia, to bring to an end distortions of competition on the art market, that objective is circumscribed by the boundaries set out in recitals 13 and 15 thereto.

29 In particular, it is apparent from those recitals that there is no need to eliminate differences between national laws which cannot be expected to affect

38 CJUE (Fourth Chamber), Case C-41/14 (Christie's France SNC V. Syndicat National des Antiquaires), request for a preliminary ruling under Article 267 TFEU from the Cour de cassation (France), judgment of 26 February 2015. the functioning of the internal market and that, in order to leave as much scope for national decision as possible, it is sufficient to limit the harmonisation exercise to those domestic provisions that have the most direct impact on the functioning of the internal market (see, to that effect, Fundación Gala-Salvador Dalí and VEGAP, EU:C:2010:191, paragraphs 27 and 31).

The criterion of distortion of the internal market is proper to the functioning of the European Union and, therefore, if used alone, may lead to counterproductive answers under the perspective of droit de suite. The issue of the management of the resale right (the procedure for its collection) is topical, left by the Directive 2001/84/EC to national legislations, with the indication that they "may provide for compulsory or optional collective management of the royalty" (article 6(2)), and that "management by a collecting society is one possibility" (Recital 28). This opens the door to options of individual management of the right, by artists themselves, which we have seen does not work in practice, and collecting societies play an important role in the effectivity and efficiency of the whole scheme. Recital 30 tries to address this concern by urging national legislations to enact "Appropriate procedures for monitoring transactions", including "a right on the part of the author or his authorised representative to obtain any necessary information from the natural or legal person liable for payment of royalties". In this sense, under article 9 of the Directive 2001/84/EC, national legislations shall provide that for a period of three years after the resale, persons entitles to receive royalty may require "any information that may be necessary in order to secure payment of royalties" from any art market professional.

This is a cause of inefficiency of the whole scheme, as it implies higher administrative costs for art market professionals that need to have the resources to face potentially great amounts of requests of information, request not necessarily in accordance with applicable regulations but still need to be answered. ${ }^{39}$ More generally, the absence of collecting society in a State makes

\footnotetext{
39 In this sense, see DESIGN AND ARTISTS COPYRIGHT SOCIETY-DACS. The management of artist's resale right in the UK. Presentation at the WIPO/SCCR International Conference on Artist's Resale Right, Geneva, Apr. 2017. The DACS provides art market professionals with an artists' search tool containing 100,000 names, a royalties calculator, a pre-sale eligibility check, and the online submission of sales information, which helps lowering the administrative burden on art market professionals as low as a median time spend per quarter to 95 minutes costing $£ 22.37$.
} 
impossible a cooperation at the international level. In a globalized art market, this lack of international cooperation is deeply detrimental to artists, as noted by the delegation of Nigeria at the WIPO/SCCR, regarding the masterpiece "Tutu" by Nigerian painter Ben Enwonwu, auctioned in London in 2018 for $£ 1.2 \mathrm{~m}$ :

The Delegation [of Nigeria] noted that Nigeria had gained some practical experience with the application of the artist resale right. The painting of a renowned Nigerian artist that had been described in the press as the Mona Lisa of Africa was recently auctioned in another country becoming the highest price paid for an African work of art in the auction market. Despite the existence of provisions on artist's resale right in the copyright legislation of Nigeria and that other country, the Nigerian artist was denied the benefit of that provision in that country simply because Nigeria was not on the list of countries that enjoyed reciprocal treatment in that country. ${ }^{40}$

This shows that the process of standardization of national legislations through the adoption of a compulsory resale royalty right at the international level needs to consider rules and procedures of its own. Rules and processes that may diverge from, or supplement, the criterion of distortion of the international art market and consider the effective protection of artists. Such guidelines can result from observation of past and current practices, and, in this context, a standard document drafted in the eighties and specific to the operation of droit de suite may be of great help.

\subsection{Draft Guiding Principles Concerning the Operation of the Droit de Suite}

Just as droit de suite itself, discussions, research and experience feedback for a more effective and uniformed scheme are all but new: as early as in 1985, model provisions were presented to the Executive Committee of the Berne Union and the Intergovernmental Committee of the Universal Copyright Convention, based on the results of a survey conducted by the Secretariat of UNESCO and the International Bureau of WIPO in national legislations. ${ }^{41}$ These "Draft Guiding Principles" take the form of five rules, divided into six chap-

\footnotetext{
40 WIPO. Draft Report from the Secretariat. Document SCCR/39/8. $39^{\text {th }}$ Session, Geneva, Oct. 21 to 25,2019 . $\$ 308$.

${ }^{41}$ BERNE UNION. Executive Committee of the International Union for the Protection of Literary and Artistic Works. Droit de suite: draft guiding principles concerning the operation of this right. Paris, 17-25 June 1985, $24^{\text {th }}$ Session.
}

ters, each of which addressing a specific issue relevant to the operation of droit de suite:

Leaving aside the differences, however, certain factors common to all the national legislations concerned can be singled out which, by revealing the same trend, can serve as a basis for the internationalization of 'droit de suite' and for drawing national laws on the subject closer to one another.

\section{$[\ldots]$}

It will then be possible for lawmakers, once the principle of the institution of 'droit de suite' has been recognized, to work out simple, universal principles of operation which will be acceptable to all in each country. ${ }^{42}$

Although more than thirty five years old, this comprehensive work of comparative law which combines legal theory and a practical approach, remains a precious analytical framework. In the next paragraphs, we will review a few of the elements identified in these Draft Guiding Principles as necessary for an effective operation of a resale royalty right worldwide, regardless of an artist original or residence. The 1985 draft addresses the issues of the works and transactions subject to resale royalty, its rate and basis for calculating, its term of applicability and beneficiaries, and the practical arrangements for its collection.

Regarding the works subject to the resale royalty, the document raises the issue of the definition of the originality of the work, and notes the great variety existing between countries, especially concerning specific types of visual art (such as, for instance, works of applied art, like tapestry or ceramics, or editions of sculptures or prints). The suggestion is to provide for an exhaustive list, noting that if on the one hand it may seem arbitrary to set a list of what is a work of art for the purposes of the resale royalty scheme, "it would certainly be much more vague and arbitrary to use general concepts such as 'works of graphic and plastic art' or 'artistic works', or to take the concept of originality alone as a general criterion for determining which works should be covered by 'droit de suite.." 43

\footnotetext{
42 BERNE UNION. Executive Committee of the International Union for the Protection of Literary and Artistic Works. Droit de suite: draft guiding principles concerning the operation of this right. Paris, 17-25 June 1985, $24^{\text {th }}$ Session. p. 3.

43 BERNE UNION. Executive Committee of the International Union for the Protection of Literary and Artistic Works. Droit de suite: draft guiding principles concerning the operation of this right. Paris, 17-25 June 1985, 24 $4^{\text {th }}$ Session. p. 24.
} 
Interestingly, neither of the examples seen above have followed this suggestion from the Draft Guiding Principles. Whereas Australia and the EU Directive have chosen a solution half-way, by including a non-exhaustive list of works, Brazil has chosen the 'vague and arbitrary' option of the general concept of original works of art or manuscripts. The list is especially extensive in the Australian Act, and completed by national regulations in the case of European Member States. The Brazilian way leads to practical problems, as art professionals may have doubts as to whether specific artworks are subject to the resale royalty, with no specialized body to refer to and have a formal position.

As regards the transactions subject to droit de suite, the second guiding principle states that it should only apply to public sales and sales made through an art dealer, regardless of the method used. This is, again, the choice of Australia and the EU. Regarding private sales proper, the authors note:

\begin{abstract}
It is conceivable that, with the development of technology, and in particular of data-processing, the difficulties of keeping a check on such sales may one day be overcome. In the meantime, it does not seem opportune to extend the application of 'droit de suite' to sales between private persons. ${ }^{44}$
\end{abstract}

Thirty five years later, technology has indeed developed tremendously, but not precisely in a way to overcome the issue of tracing and identifying purely private sales. In this sense, the option in the Brazilian Copyright Act is clearly not adequate.

The third guiding principle calls for a $5 \%$ rate on the selling price before any deduction, not applicable "if the selling price is less than USD 50 to USD 100 or if the work is resold at a price lower than the price paid by the seller, the onus of proof resting on the latter." The Australian Act is the closest to this mechanism, with the same fixed rate and threshold under which the royalty does not apply. The Directive 2001/84/EC sets progressive rates, a solution that is more complex but addresses better the risks of relocations of sales of artworks outside the EU. Interestingly, the Guiding Principles provide that the seller may avoid the payment of the royalty if he/she may prove that the resale price is lower than the price of acquisition, solution that seems

44 BERNE UNION. Executive Committee of the International Union for the Protection of Literary and Artistic Works. Droit de suite: draft guiding principles concerning the operation of this right. Paris, 17-25 June 1985, $24^{\text {th }}$ Session. p. 33. reasonable as the seller is the one with all the necessary information.

The fourth principle brings guidance on the term of applicability and the beneficiaries of the resale right, and especially the fact that it is inalienable and cannot be renounced. For it is certainly the most fundamental feature of the droit de suite, already addressed in the Berne Convention, it is not subject to much debate and is common to all the examples above.

The last principle concerns practical arrangement for the collection of the resale royalty. In particular, it provides for an obligation for intermediaries in a sale of a work of art subject to the royalty to collect this royalty and "forward it to the artist or his representative within a period of one month from the date of the sale". This active obligation of art market professionals may come to represent a substantive administrative cost and has no equivalent in any of the examples brought earlier. Australia channels this obligation of information to the collecting society, and the European Directive provides for a right of information of the eventual beneficiaries of resale royalty. Brazil, again, is silent.

This guiding principle further provides for the joint and several liability of the seller, the buyer and the intermediary for the payment of the royalty. This liability is also determined, in a certain way, by Australian Act; it is addressed in the European Directive to be left to the Member States; and it is absent of the Brazilian Copyright Act, which stipulates for the sole liability of the seller (in private sales) or the intermediary (in sales in which art market professionals participate). If the seller may remain the ultimate person liable for the payment of the royalty, one may see the practicality of holding the buyer jointly liable, especially in situations where the seller sales the artwork out of economic distress and the buyer is in a good financial situation.

Regarding requests of information to be addressed to art market professionals, on possible transactions that may fall under the resale royalty scheme, the document reserves such outstanding powers to "a copyright agency bound to professional secrecy". It seems a fair balance between the necessities of the operationality of the resale royalty scheme, the confidential nature of the information involved, and the secrecy that is a characteristic feature of the art market. Here again, similar provisions may be found in the Australian Act, which provides for exchanges of information between art ma- 
rket professionals and the Copyright Agency. On the contrary, Directive 2001/84/EC opens this right to any potential beneficiary and Brazil is, again, silent.

It is especially relevant that this last guiding principle is the most detailed, as it is key to the effectivity of the whole scheme. ${ }^{45}$ The existence of a specialized agency for the collective management of the resale right is also central. As the document notes:

\begin{abstract}
In the following countries, 'droit de suite' is recognized only as a principle and no special procedure for levying dues has been provided for: $[\ldots]$ Brazil $[\ldots]$. In the absence, then, of any legislative provision, the parties concerned, i.e. artists, on the one hand, and those professionally involved in the art market (auctioneers and art galleries in particular), on the other hand, are left responsible for making arrangements with one another and giving practical effect to the 'droit de suite' system.

Even if in the most favourable cases, artists are organized into professional associations, however, the balance of power is unequal and most of the time negotiation is impossible. [...]

More generally, it is to be noted that the only countries which have effectively implemented 'droit de suite' are also those which, irrespective of the practical arrangements made by the legislator for the collection of the levy, have active and efficient national societies of authors: SPADEM and ADAGP in France, SABAM in Belgium, BILDKUNST in the Federal Republic of Germany, and ARTS FUND in Hungary. ${ }^{46}$
\end{abstract}

This document is based on the situation under the former Brazilian copyright act, but it remains valid under the new Copyright Act, and is one of the main causes of the absence of 'practical effect to the 'droit de suite' system' in Brazil. More generally, the comparison of these Guiding Principles with the examples of Australia, Brazil and the European Union shows that in spite of being drafted more than thirty-five years ago, they remain a primary document, with observations and suggestions that are still crucial for an effective resale right scheme.

\footnotetext{
45 See FARCHY, Joëlle; GRADDY, Kathryn. The economic implications of the artist's resale right. Geneva, 28 Apr. 2017. WIPO. Document SCCR/35/7, 2017. p. 18: "Beyond the debate on the existence or absence of the resale right in a given geographical area, the actual implementing mechanisms are particularly important. Depending on these mechanisms, the effect of the resale right on the market as a whole may vary widely."

46 BERNE UNION. Executive Committee of the International Union for the Protection of Literary and Artistic Works. Droit de suite: draft guiding principles concerning the operation of this right. Paris, 17-25 June 1985, 24 ${ }^{\text {th }}$ Session. p. 61 and 69, respectively.
}

While Australia and the EU follow in a large part these Guiding Principles and show actual good results, Brazil mostly ignores them and its direito de sequência remains highly hypothetical and problematic in practice. The European Union has had to deviate from them on certain points and address pressures of national art markets, and Australia, with the most recent regulation, seems to have added the European experience to the suggestions of the Guiding Principles. It shows interestingly that despite the social and technical transformations of the last three decades - and especially the Internet and the digital economy - the issues around the effectivity of the droit de suite remain the same.

\section{Concluding remarks}

In their general conclusion, the Draft Guiding Principles point out that if "Some measure of uniformity might have been achieved by introducing the system of 'droit de suite' into an international convention", "efforts to include 'droit de suite' in the Universal Convention have been unsuccessful, and the Berne Convention does no more than set out principles in this regard." Due to original gap, one century after its creation, droit de suite remains highly hypothetical for many visual artists and their families, even in countries that formally recognize it.

This paper has identified to major issues to the effectivity of the resale right nowadays: a lack of definition of the core elements necessary for its operationality, and a lack of homogeneity among the countries that do apply it, which undermines the application of the principle of reciprocity. In this perspective, the national delegations at WIPO will need to discuss and agree not only on the compulsory nature of Article 14ter of the Berne Convention, but also address on the core characteristics of the resale right. ${ }^{47}$ Otherwise, there will still be opposite examples as Brazil and Australia, and visual artists will continue to benefit from varying rights depending on their nationality or place of residence, which is not the case for other artists, such as musicians and

\footnotetext{
47 In this sense, see, for instance, the draft international treaty on droit de suite proposed by Prof. RICKETSON, Sam. Proposed international treaty on droit de suite/ resale royalty right for visual artists. June 2015. Available at: https://www.cisac.org/services/policy/visualartists-resale-right. Last access: 26 Mar. 2021.
} 
writers, for example. ${ }^{48}$ For this, the experience of the European Union and the Directive 2001/84/EC will prove much helpful in determining the criteria(um) for the degree of standardization to be reached.

As such multilateral negotiations will necessarily take time to reach this ultimate goal, countries that have still not recognized the droit de suite, and countries where it exists but is not effective can, without waiting, build on positive experiences and existing studies. Brazil, specifically - as it is at the origin of this paper - may easily overcome the obstacles to the effectivity of its direito de sequência. In this process, the Draft Guiding Principles should be seen as an essential working document, as it provides a detailed comparative study with a practical approach. A priority may be the indication of a collective society responsible for operationalizing the scheme. Such specialized agency would intermediate the relationship between artists and ark market professionals; implement mechanisms to facilitate the management and payment of the royalty, reducing administrative costs; and, more basically, generate data to have an actual picture of the situation and allow analysis. This would not even require a major reform of the Brazilian Copyright Act, since such agencies already exist and have had their status and regime specified in 2013 by Law No. $12.853 .^{49}$

\section{References}

ABRÃO, Eliane Yachouh. Direitos autorais: conceito, violações e prova. Revista do Instituto dos Advogados de São Paulo, v. 27, p. 107-121, jan./jun. 2011.

ABRÃO, Eliane Yachouh. Sociedades de gestão coletiva de direitos autorais e as modificações trazidas pela Lei 12.853, de 18.08.2013. Revista do Instituto dos Advogados de São Paulo, v. 32, p. 397-402, jul./dez. 2013.

ASCENSÃO, José Oliveira. A pretensa "propriedade" intelectual. Doutrinas Essenciais de Direito Empresarial, v. 1, p. 1283-1306, dez. 2010.

AUSTRALIA. Department of Communication and the

\footnotetext{
48 MACKAY, Erin. Australian visual artists: joining the resale rights arena. Indigenous Law Bulletin, v. 7, n. 5, p. 2, 2008.

${ }_{49}$ ABRÃO, Eliane Yachouh. Direitos autorais: conceito, violações e prova. Revista do Instituto dos Advogados de São Paulo, v. 27, p. 107-121, jan./jun. 2011.
}

Arts. Post-Implementation Review: Resale Royalty Right for Visual Artists Act 2009 and the resale royalty scheme. 23 Dec. 2019.

BERNE UNION. Executive Committee of the International Union for the Protection of Literary and Artistic Works. Droit de suite: draft guiding principles concerning the operation of this right. Paris, 17-25 June 1985, $24^{\text {th }}$ Session.

BUSSEY, Alexander. The incompatibility of droit de suite with common law theories of copyright. Fordham Intellectual Property Media \& Entertainment Law Journal, n. 1063, 2013.

DE-MATTIA, Fábio Maria. Droit de suite ou direito de sequência das obras intelectuais. Revista dos Tribunais, v. 741, p. 58, jul. 1997.

DESIGN AND ARTISTS COPYRIGHT SOCIETYDACS. The management of artist's resale right in the UK. Presentation at the WIPO/SCCR International Conference on Artist's Resale Right, Geneva, Apr. 2017.

FARCHY, Joëlle; GRADDY, Kathryn. The economic implications of the artist's resale right. Geneva, 28 Apr. 2017. WIPO. Document SCCR/35/7, 2017.

FERRY-FALL, Marie-Anne. The resale right in France. Presentation at the WIPO/SCCR International Conference on Artist's Resale Right, Geneva, Apr. 2017.

MACKAY, Erin. Australian visual artists: joining the resale rights arena. Indigenous Law Bulletin, v. 7, n. 5, p. 2, 2008.

MACKAY, Erin. Indigenous traditional knowledge, copyright and art: shortcomings in protection and an alternative approach. UNSW Law Journal, v. 32, n. 1, 2009.

PFENNIG, Gerhard. The resale right of artists (droit de suite). Copyright Bulletin, v. 31, n. 3, p. 20, Jul./Sep. 1997.

PHAM, Lan. The resale royalty right: what does it mean for indigenous artists?. Indigenous Law Bulletin, v. 7, n. 20, p. 21, 2010.

RICKETSON, Sam. Proposed international treaty on droit de suite/ resale royalty right for visual artists. June 2015. Available at: https://www.cisac.org/services/policy/visualartists-resale-right. Last access: 26 Mar. 2021.

SILVA FILHO, Artur Marques da. Conteúdo dos direitos do autor. Revista dos Tribunais, v. 806, p. 11-27, dez. 2002. 
UNESCO and WIPO. Tunis model law on copyright. Copyright, n. 7-8, July/Aug. 1976.

WIPO. Draft Report from the Secretariat. Document SCCR $/ 36 / 8.36^{\text {th }}$ Session, Geneva, May 28 to June 1, 2018.

WIPO. Draft Report from the Secretariat. Document SCCR/37/9. $37^{\text {th }}$ Session, Geneva, Nov. 26 to 30, 2018.

WIPO. Draft Report from the Secretariat. Document SCCR/38/11. 38 $8^{\text {th }}$ Session Geneva, Apr. 1 to 5, 2019.

WIPO. Draft Report from the Secretariat. Document SCCR/39/8. 39 th Session, Geneva, Oct. 21 to 25, 2019.
WIPO. Next steps on Other Matters proposed by the Chair. Document SCCR/36/4.36 ${ }^{\text {th }}$ Session, Geneva, May 28 to June 1, 2018.

WIPO. Standing Committee on Copyright and Related Rights. Document SCCR/31//5. 31 $1^{\text {st }}$ Session, Geneva, Dec. 7 to 11, 2015.

WIPO. Task Force on the Artist's Resale Royalty Right. Document SCCR/37/5.37 $37^{\text {th }}$ Session, Geneva, Nov. 26 to 30, 2018. 
Para publicar na Revista de Direito Internacional, acesse o endereço eletrônico www.rdi.uniceub.br ou www.brazilianjournal.org.

Observe as normas de publicação, para facilitar e agilizar o trabalho de edição. 